\title{
NEDESTRUKTIVNÍ METODY PRO STANOVENÍ TRVANLIVOSTI CIHEL PLNÝCH PÁLENÝCH PŘI REKONSTRUKCI HISTORICKÝCH STAVEB
}

\author{
NON-DESTRUCTIVE METHODS FOR DETERMINING THE DURABILITY \\ OF SOLID FIRED BRICKS DURING RECONSTRUCTION OF \\ HISTORICAL BUILDINGS
}

Vojtěch Bartoň ${ }^{*}, 1$, Jaroslav Šnédar ${ }^{1}$, Petr Cikrle ${ }^{1}$

*176012@vutbr.cz

${ }^{1}$ Vysoké učení technické v Brně, Fakulta stavební, Veveři 331/95, 60200 Brno, Czech Republic

\begin{abstract}
Abstrakt
Tento článek pojednává o současných nedestruktivních možnostech stanovení trvanlivosti cihel plných pálených během rekonstrukcí historických a památkových objektů. Trvanlivost zdících prvků úzce souvisí s vadami ve vnitřní struktuře prvků, které jsou zpravidla neviditelné na povrchu. Aby bylo možné stanovit trvanlivosti zdících prvků, musíme tedy "nahlédnout" do jejich vnitřní struktury. Pro tento účel byly v této práci využité nedestruktivní metody jako je ultrazvuková impulsní metoda nebo rezonanční impulsní metoda. Využitelnost těchto nedestruktivních metod byla ověřena in-situ, a to na historickém mostu nedaleko obce Mikulov.
\end{abstract}

Klíčová slova

Nedestruktivní testování, rezonanční impulsní metoda, ultrazvuková impulsní metoda, cihla plná pálená

\begin{abstract}
This article deals with the contemporary non-destructive possibilities of determining the durability of solid fired bricks during the reconstruction of historical and monumental buildings. The durability of the solid fired bricks is closely related to the defects in the internal structure of the elements, which are usually invisible on the surface. To be possible to determine the durability of solid fired bricks, we must "look" into their internal structure. For this purpose, non-destructive methods such as ultrasonic pulse method or resonant pulse method were used in this work. The usability of these non-destructive methods was verified in-situ, on a historic bridge near the village of Mikulov.
\end{abstract}

\section{Key words}

Non-destructive testing (NDT), resonant impuls method, ultrasonic pulse method, solid fired brick

\section{1 ÚVOD}

Během rekonstrukcí historických a památkových objektů z cihelného zdiva nastává otázka, zda pro rekonstrukci využít novodobé zdící prvky (vyrobené moderními technologiemi), anebo zda znovu využít historické zdící prvky získané ze zbouraných objektů. Oba z těchto přístupů mají jistě své výhody i nevýhody. Při využití novodobých zdících prvků je lepší předpoklad rovnoměrnosti kvality jednotlivých prvkủ. Výhoda znovu využití historických prvků (tzv. "upcyklace") spočívá především v autentičnosti cihelného zdiva. Jedná se také o ekologičtější způsob rekonstrukce památek, protože není zapotřebí výroba nového stavebního materiálu.

Především v př́padě rekonstrukce památkových staveb historickými cihlami plnými pálenými je potřeba pečlivě sledovat kvalitu každého jednotlivého zdícího prvku. U prvků, které mají být zabudované do konstrukce cihelné stavby je potřeba sledovat řadu faktorů. Část z těchto faktorů lze posoudit pouze na základě vizuální kontroly prvků. Jedná se např́ílad o geometrii prvků, tedy jeho rozměry ale také například nežádoucí změny v geometrii jako je zkroucení prvků vlivem nadměrné teploty výpalu. Dalším faktorem pro zabudování prvků do konstrukce může být i jejich zbarvení (kvůli autentičnost zdiva). Před zabudováním historických prvků do konstrukce je potřeba posoudit, zda prvek neobsahuje vady a poruchy. Vady a poruchy jako jsou např́íklad trhliny nebo odštěpky, které se objevují na povrchu prvkůa a lze je tak odhalit pouze vizuální prohlídkou. V cihlách plných 
pálených se však mohou objevovat také vady ve vnitřní struktuře prvků, které nejsou na povrchu viditelné. Přítomnost vad ve vnitřní struktuře prvků úzce souvisí s jejich trvanlivostí, a to především u prvků, které jsou vystaveny povětrnostním podmínkám. Trvanlivost neboli schopnost materiálů odolávat povětrnostním podmínkám úzce souvisí s jejich mrazuvzdorností (schopností odolávat opakovanému zmrazování a rozmrazování bez jejich porušení). Vlivem rozpínání a smrštování při přeměně vody na led dochází v prvku nebo konstrukci ke vzniku velkých napětí [1]. Tato napětí vznikají v pórech nebo vnitřní struktuře keramických výrobků. $\mathrm{S}$ narůstajícím počtem zmrazovacích cyklů dochází k jejich rozvoji. Cihly plné pálené mají zpravidla vysokou nasákavost a jsou tak náchylnější k poškození mrazem než jiné materiály [2].

Při výběru (trrídění) zdících prvků pro rekonstrukci cihelných objektů se dnes stále použivá obdoba trasovací akustické metody. Jedná se o banální metodu, kdy na základě akustické odezvy od úderu impulsního kladívka (do zkoušeného prvku) lze usuzovat na př́ítomnost vad ve vnitřní struktuře. Akustické odezvy lze označit jako zvonivá, dunivá anebo křaplavá [3]. Zvonivá odezva u prvků nastane v př́padě, že vypalovací teplota u daného prvku byla dostatečně vysoká a v prvku se pravděpodobně nenachází vady ani poruchy ve vnitřní struktuře. V prrípadě dunivé odezvy lze předpokládat, že teplota výpalu nebyla dostatečná. Z důvodů nízké teploty výpalu bude mít prvek větší nasákavost, bude tak náchylnější $\mathrm{k}$ poškození vlivem povětrnostních podmínek. V posledním případě, tedy v případě, že akustická odezva je křaplavá, můžeme předpokládat, že se v prvku nachází trhliny, které nemusí být na povrchu prvku viditelné. Takovýto prvek bude mít rovněž sníženou trvanlivost, nebot' vlivem rozpínání při přeměně vody na led $\mathrm{v}$ trhlinách bude docházet $\mathrm{k}$ jejich opakovanému rozšiřování až do samotného porušení prvku.

Sledování kvality zdících prvků tímto způsobem se v dnešní době jeví jako zcela nedostatečné. Metoda je pouze přibližná a nedokáže proto odhalit veškeré vady a poruchy ve vnitřní struktuře prvků, které mohou podstatným způsobem snížit jejich trvanlivost. Při využití této metody navíc záleží na individuálním posouzení pracovníka, který musí mít řadu zkušeností, což je také velkou nevýhodou této metody, nebot' takto zkušených pracovníků v posledních letech výrazně ubývá.

Z těchto důvodi̊ se jeví jako opodstatněné využití moderních metod a technologií, např́íklad rezonanční impulsní metoda nebo ultrazvuková impulsní metoda pro predikci trvanlivosti historických zdících prvků.

Cihelný most u obce Mikulov může být př́kladem rekonstrukce historické stavby s využitím "upcyklace" historických cihel plných pálených získaných ze zbouraných cihelných objektů.

\section{Cihelný most u Mikulova}

Barokní cihlový most, který se nachází nedaleko od Česko - Rakouských státních hranic (mezi obcemi Mikulov, Sedlec a Drasenhofen) je jedinečný hned z několika důvodů. Jeho jedinečnost spočívá především v použitém materiálu. Most je postaven z cihel plných pálených (kámen byl použit pouze v patě pilířu), což nebylo v minulosti obvyklé. U konstrukcí tohoto typu se setkáme spíše s kamenným kusovým stavivem, které má zpravidla lepší trvanlivost. Další výjimečností tohoto mostu je jeho délka, která činí $100 \mathrm{~m}$. Most je tvořen celkem patnácti cihlovými klenbami. Ve spojení s touto stavbou je také vhodné se zmínit o důmyslném způsobu odvodnění mostovky. Voda byla z mostu odváděna pomocí vyspádované vápencové dlažby (mohla z mostu odtékat a zároveň nebylo bráněno odpařování vody ze spodní stavby mostu). Aby voda volně nestékala po mostu, byla odváděná pomocí keramických žlábků (prejzů) [4].

Most byl postaven přibližně ve dvacátých letech sedmnáctého století a tvořil jedinou cestu přes nový rybník k zámečku Portz (lovecký zámeček či Lusthaus), který se nacházel na Tichém ostrově (Inselu) u obce Mikulov (Obr. 1). Stavba železnice v 19. století však zcela změnila charakter ostrova, ze kterého se stává poloostrov a území tak přestává být lukrativní lokalitou. Unikátní cihelný most, tak po dlouhá léta chátrá, zarůstá vegetací a je zanesen nánosy bahna (Obr. 2). Naděje na záchranu mostu vznikla v r. 2016, kdy započal projekt na jeho obnovu [4], [5].
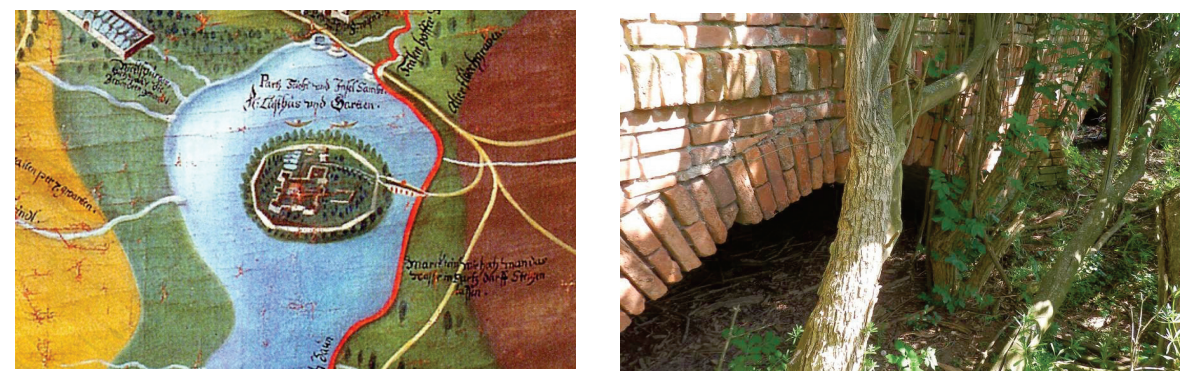

Obr. 1 Č́st malby s kartografickým zobrazením mikulovského panství z roku 1672 (vlevo) [5].

Obr. 2 Cihelný most u Mikulova - před zahájením rekonstrukce (vpravo) [4]. 


\section{MODERNÍ MOŽNOSTI PREDIKCE TRVANLIVOSTI ZDÍCÍCH PRVKŮ}

Pro odhalení vad ve vnitřní struktuře historických cihel plných pálených pro rekonstrukce zděných objektů byly v této práci využity zcela nedestruktivní elektroakustické metody, jmenovitě ultrazvuková impulsní metoda a rezonanční impulsní metoda. Ve spojení s touto problematikou je také vhodné zmínit metodu impact-echo, kterou lze také odhalit vady ve vnitřní struktuře prvků. Tato metoda však nebyla v této práci využita a není proto dále rozebírána.

\section{Ultrazvuková impulsní metoda}

Ultrazvuková impulsní metoda (dále jen UZ) se ve stavebnictví využívá zejména pro sledování vlastností betonových konstrukcí a dílců. Tato metoda je však aplikovatelná i na jiné materiály jako jsou právě cihly plné pálené. Sledovanou vlastností může být například pevnost betonu, častěji je však metoda využívána k posouzení rovnoměrnosti betonu. Pomocí této metody lze stanovit také dynamické moduly pružnosti a v neposlední řadě lze pomocí této metody odhalit vady ve vnitřní struktuře prvků, touto problematikou se zabývá např́iklad norma ČSN 731380 (731380).

Princip metody je založen na mechanickém vlnění částic prostředím s frekvencí vyšší než $20 \mathrm{kHz}$, ve stavebnictví se používají frekvence až do $150 \mathrm{kHz}$. Stanovení vlastností materiálu či prvků lze zjištěním dob průchodu ultrazvukových vln (vypovídá o fyzikálně/mechanických vlastnostech materiálu, ale i o př́padných defektech), anebo je možné využít metodu odrazovou (zachycuje odraz ultrazvukových impulsu od nehomogenit, defektů apod). Prozvučování lze rozdělit na tř́i základní způsoby, a to př́ímé, polopř́mé a povrchové [3], [6].
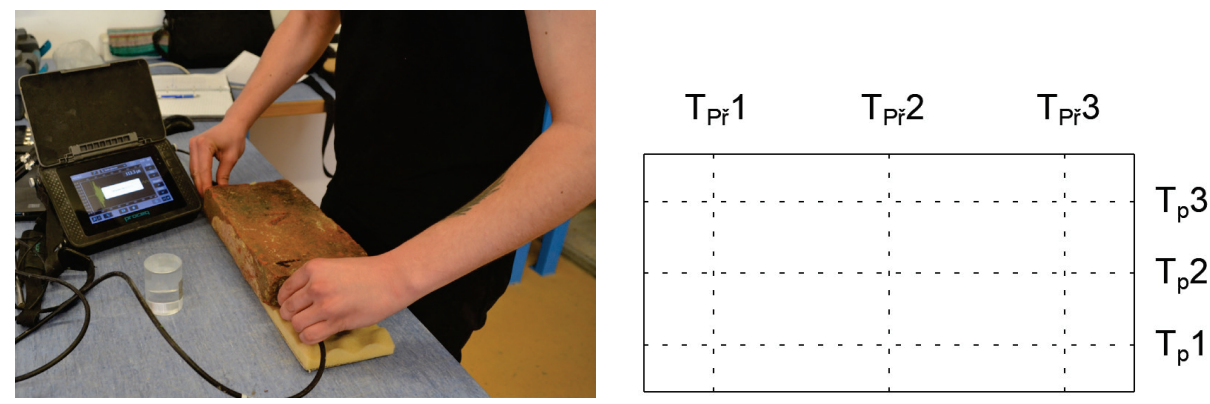

Obr. 3 Stanovení dob průchodu UZ vln přímým prozvučováním v podélném směru prvku (vlevo).

Obr. 4 Schéma linií pro stanovení dob průchodu UZ vln - v podélném (Tp) a příčném směru (Tpř) (vpravo).

Pro účely této práce byly stanovené doby průchodu, způsobem přímého prozvučování (Obr. 3). Měření je vhodné provést jak v podélném směru $\left(T_{p}\right)$, tak v příčném směru $\left(T_{\text {pr̆ }}\right)$ prvku, a to vždy ve třech liniích $(O b r .4)$, aby bylo možné zachytit veškeré defekty ve vnitřní struktuře prvku. V této práci bylo pro stanovení dob průchodu ultrazvukových vln využito př́istroje Pundit PL-200 od společnosti Proceq.

\section{Rezonanční impulsní metoda}

Další metodou, pomocí které lze predikovat trvanlivost zdících prvků na základě identifikace vad ve vnitřní struktuře prvků je právě rezonanční impulsní metoda.

Vlivem vnějšího impulsu (úder impulsního kladívka - Obr. 5) dochází u každého prvku z tuhého materiálu k jeho rozkmitání. V prrípadě, že frekvence vlastního kmitání prvku je totožná s frekvencí vneseného impulsu, dochází k jevu, který nazýváme rezonancí. Existuje celá řada druhů kmitání, pro stanovení vlastností prvků se však zpravidla určují pouze tři typy prvních vlastních frekvencí, a to první vlastní frekvence podélného fl, kroutivého $\mathrm{f}_{\mathrm{t}}$ a př́ičného $\mathrm{f}_{\mathrm{f}}$ kmitání [7]. 

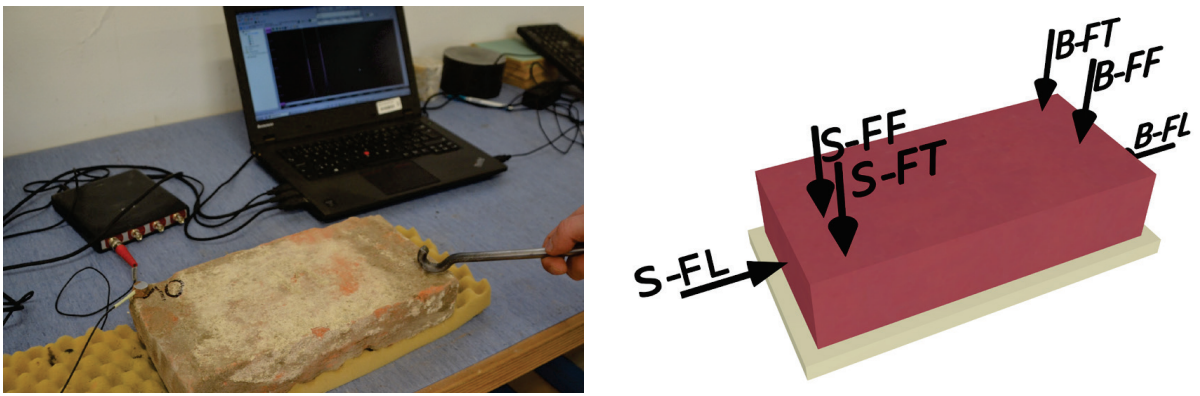

Obr. 5 Sestava pro stanovení prvních vlastních frekvencí rezonanční impulsní metodou (vlevo).

Obr. 6 Rozmístění budičů („,B“) a snímačů (,,S“) pro podélné, kroutivé a příčné kmitání (vpravo).

Pro každý z těchto druhů kmitání jsou známá místa kmiten (místa s největší amplitudou), do kterých jsou umist'ovány snímače a budiče (Obr. 6).

Výhodou této metody je fakt, že kromě samotných hodnot vlastních frekvencí jsme schopni zaznamenat celé spektrum frekvencí. Následně lze pomocí průběhu křivky odhalit, respektive sledovat rozvoj vad ve vnitřní struktuře.

\section{METODIKA MĚŘENÍ}

V roce 2016 započaly přípravy k obnově a zpřístupnění mostu u Mikulova. Samotná obnova začala v roce 2018 a trvala dva roky. Pro obnovu cihelného mostu bylo rozhodnuto znovu využít historické zděné prvky.

Z části se jednalo o zdící prvky, které byly již v minulosti zabudované v konstrukci mostu. Tyto zdící prvky pocházely z nedaleké cihelny v Mikulově (tehdejší Nicolsburg), jak dokazuje jejich negativní kolek s nápisem "N" [4]. Tyto zdící prvky svou kvalitou a trvanlivostí předčí většinu novodobých cihel plných pálených, a to i přes fakt že pochází již ze 17. století. Těchto zdících prvků však nebyl dostatek a bylo nutné získat zdící prvky z jiných zbouraných staveb. Zbytek získaných zdících prvků pocházel z různých cihelen, a dokonce i z jiných časových období. Zdící prvky jsou proto rozdílné ve své kvalitě a trvanlivosti.

Pro řešitele tohoto projektu se naskytla jedinečná možnost ověřit použitelnost výše uvedených metod během rekonstrukce historického cihelného mostu. Během rekonstrukce byla řada zdících prvků testována rezonanční impulsní metodou a ultrazvukovou impulsní metodou (Obr. 7).
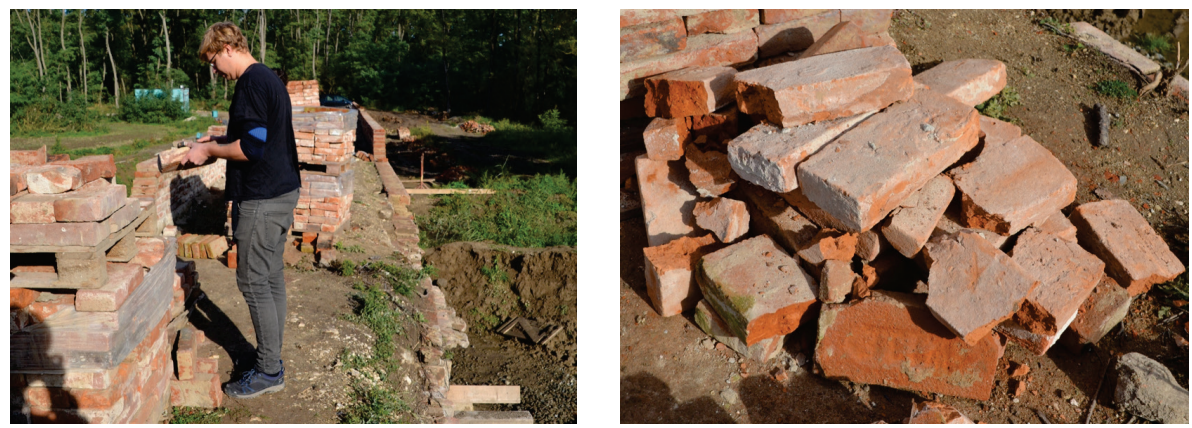

Obr. 7 Zkoušky zdících prvků během rekonstrukce cihelného mostu u Mikulova (vlevo).

Obr. 8 Zdící prvky vyřazené během rekonstrukce cihelného mostu u Mikulova (vpravo).

Č́st zdících prvků byla vyřazena již na stavbě jako nevhodná pro použití do konstrukce (Obr. 8). Na základě měření in-situ během obnovy mostu bylo vytypováno 10 zdících prvků nízké kvality a 10 zdících prvků $\mathrm{s}$ předpoklady pro velmi dobrou kvalitu i trvanlivost. Tyto prvky byly dovezeny do laboratoře, kde byly podrobeny zkoušce mrazuvzdornosti (Obr. 9) dle [8]. Po 25 zmrazovacích cyklech byla u prvků stanovená také pevnost v tahu za ohybu (Obr. 10) a následně pevnost v tlaku dle [9]. 

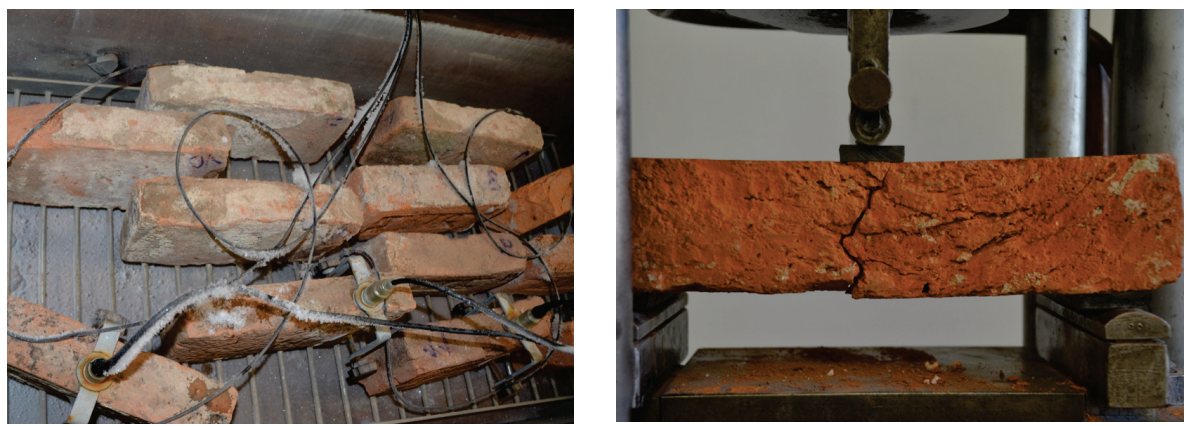

Obr. 9 Zkouška mrazuvzdornosti odebraných vzorků při obnově mostu u Mikulova (vlevo).

Obr. 10 Zkouška pevnosti v tahu za ohybu odebraného vzorku při obnově mostu u Mikulova (vpravo).

\section{VÝSLEDKY}

Laboratorními zkouškami (stanovení mrazuvzdornosti, pevnost v tahu za ohybu a pevnost v tlaku) se potvrdily prvotní odhady trvanlivosti a kvality zdících prvků provedené in-situ nedestruktivními metodami. Odhady in-situ byly provedeny pomocí prvních vlastních frekvencí podélného, př́icného a kroutivého kmitání stanovené rezonanční impulsní metodou. Odhady kvality a trvanlivosti zdících prvků stanovené rezonanční metodou se shodovaly s odhady provedenými pomocí dob průchodu ultrazvukových vln zjištěných pomocí ultrazvukové impulsní metody.
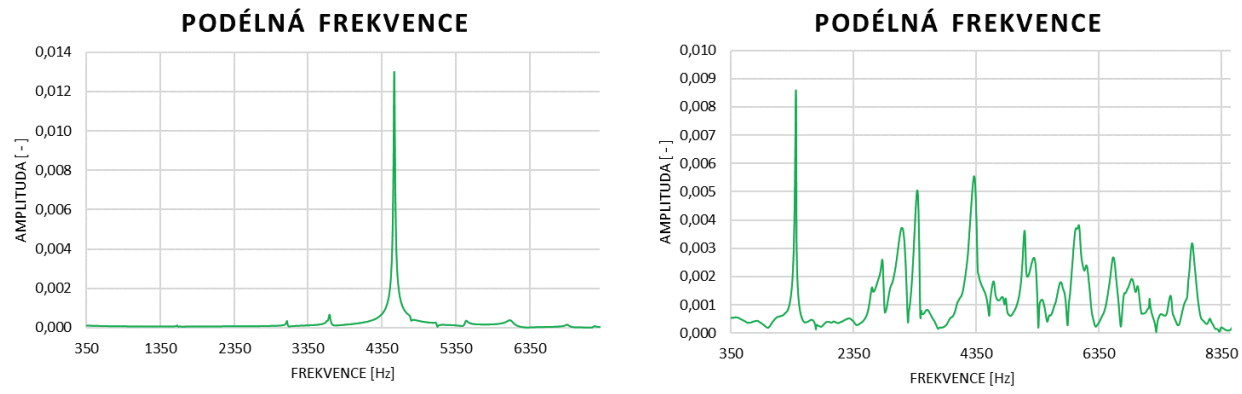

Obr. 11 Spektrum frekvencí podélného kmitání - kvalitní zdící prvek (vlevo).

Obr. 12 Spektrum frekvencí podélného kmitání - nekvalitní zdící prvek (vpravo).

U zdících prvků, které vykazovali vysoké hodnoty prvních vlastních frekvencí a průběh spektra frekvencí měl jednoznačný vrchol (Obr. 11) byly také doby průchodu ultrazvukových vln kratší. Tyto prvky i po 25 zmrazovacích cyklech nevykazovaly zjevné defekty a hodnoty pevností v tlaku byly stále vysoké (přibližně $20 \mathrm{MPa}$ ).

Naopak u zdících prvků, u kterých nebylo téměř možné určit hodnoty prvních vlastních frekvencí, protože průběh spektra frekvencí nebyl jednoznačný (Obr. 12), byly i doby průchodu ultrazvukových vln o poznání delší. Tento fakt poukazuje na vady ve vnitřní struktuře těchto prvků, což se potvrdilo laboratorními zkouškami. U těchto prvků nebylo ve většině prrípadů možné stanovit pevnosti po 25 zmrazovacích cyklech, nebot' došlo k rozpadu prvků již do 10. zmrazovacího cyklu.

\section{DISKUZE}

Tato práce se zabývá kvalitou pouze zdicích prvků pro jejich použití při rekonstrukcích historických a památkových objektů. Cihelné zdivo je však kompozitní materiál a při rekonstrukcích těchto objektů je nutné dbát zvýšené pozornosti na použitou maltu, ale i na samotné provedení stavby (Obr. 13). Pečlivý výběr zdících prvků je bezesporu důležitý, pokud je však konstrukce staveb navržena a provede tak, že je zabráněno pronikání 
vlhkosti do cihelného zdiva, může i nekvalitní zdící prvek vydržet bez porušení dlouhá léta (Obr. 13). V opačném př́padě může i kvalitní zdící prvek vykazovat defekty již po několika zimních obdobích (Obr. 14).
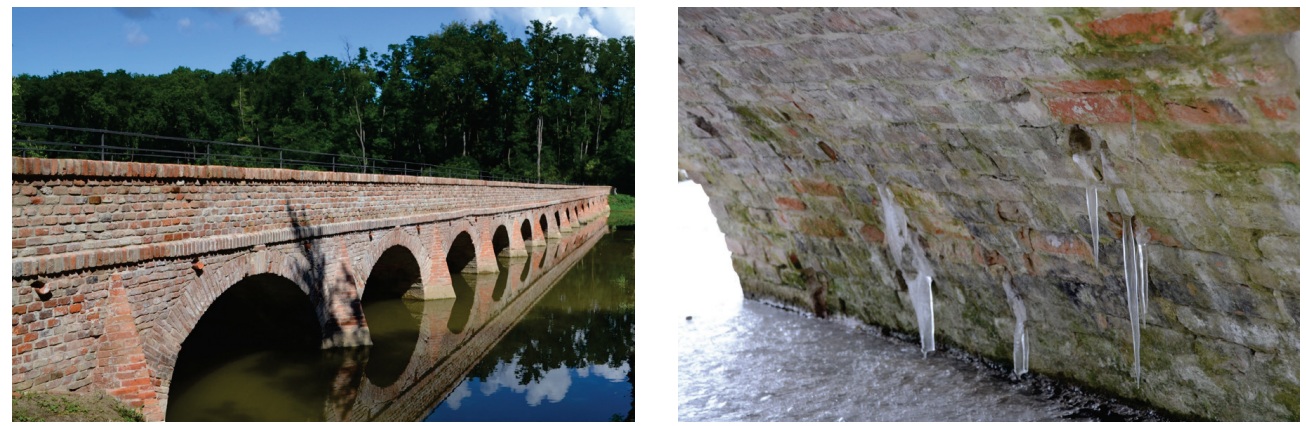

Obr. 13 Cihelný most u Mikulova po rekonstrukci (vlevo).

Obr. 14 Zatékání do nosné konstrukce mostu (vpravo).

Kvalita a trvanlivost zdících prvků úzce souvisí s vadami a poruchami ve vnitřní struktuře prvků. Tyto defekty nejsme schopni odhalit pouze vizuální prohlídkou, proto se použití moderních technologií, jako je rezonanční impulsní metoda nebo ultrazvuková impulsní metoda, jeví jako logické. Tyto metody jsou jednoduché na provádění a lze je použít přímo během rekonstrukcí historických objektů.

\section{ZÁVĚR}

Výsledky této práce potvrdily předpoklady vhodnosti použití nedestruktivních metod pro stanovení kvality zdících prvků (cihel plných pálených). Predikce trvanlivosti provedená přímo na stavbě pomocí rezonanční impulsní metody a ultrazvukové metody se shodovala s laboratorními zkouškami. Prvky, které byly nedestruktivními metodami vyhodnocené jako nekvalitní, vykazovaly značné defekty již po desátém zmrazovacím cyklu. U těchto prvků proto nebylo možné stanovit mechanické vlastnosti po 25 zmrazovacích cyklech, protože došlo k jejich rozpadu. Naopak prvky, které byly vyhodnocené nedestruktivními metodami jako kvalitní, nevykazovaly defekty ani po 25 zmrazovacích cyklech a jejich pevnosti v tlaku se stále pohybovaly okolo $20 \mathrm{MPa}$.

Z těchto důvodů se rezonanční impulsní metoda nebo ultrazvuková impulsní metoda jeví jako velmi vhodná $\mathrm{k}$ tomuto účelu a do budoucna bude př́nosné použití těchto metod v dané problematice dále rozvíjet.

\section{Použité zdroje}

[1] MARSHALL, Ducan, Derek WORTHING, Roger HEALTH a Nigel DANN. Understanding Housing Defects: Edition 4. Milton Park, Abingdon-on-Thames, Oxfordshire United Kingdom: Routledge Taylor \& Francis Group, 2013. ISBN 9781136153730.

[2] CARTER, C. Barry a M. Grant NORTON. Ceramic materials: science and engineering. Second edition. New York: Springer, 2013. ISBN 978-1-4614-3523-5.

[3] HOBST, Leonard, Jiří ADÁMEK, Petr CIKRLE a Pavel SCHMID. Diagnostika stavebních konstrukcí: přednášky. Brno. Studijní opory. VUT.

[4] Http://www.mikulov.cz: Projekt Portz Insel [online]. [cit. 2021-11-25]. Dostupné z: http://www.mikulov.cz/turistika/pamatky-a-prohlidkove-objekty/portz-insel/projekt-portz-insel/

[5] SEDLÁČEK, Tomáš. Zámeček Portz. Https://www.npu.cz [online]. [cit. 2019-12-01]. Dostupné z: https://www.npu.cz/cs/generalni-reditelstvi-npu/inspirujte-se/6008-zamecek-portz

[6] ČSN 73 1371: Nedestruktivní zkoušení betonu - Ultrazvuková impulzová metoda zkoušení betonu. 1. Praha: Úřad pro technickou normalizaci, metrologii a státní zkušebnictví., 2011.

[7] ČSN 73 1372: Nedestruktivní zkoušení betonu - Rezonanční metoda zkoušení betonu. -. Praha: Úřad pro technickou normalizaci, metrologii a státní zkušebnictví, 2012.

[8] ČSN 72 2609: Zkušební metody pro zdicí prvky - Specifické vlastnosti pálených zdicích prvků. -. Praha: Úřad pro technickou normalizaci, metrologii a státní zkušebnictví, 2017.

[9] ČSN EN 772-1+A1 (722635) Zkušební metody pro zdící prvky. Praha: Úřad pro technickou normalizaci, metrologii a státní zkušebnictví, 2016 